\title{
Enforcement of Intellectual Property Rights - Blessing or Curse? A Perspective from Mauritius ${ }^{1}$
}

\author{
Kaushik Goburdhun*
}

\begin{abstract}
The Mauritian economy is facing serious economic difficulties, and the government is being pressurised to maintain the competitive edge of various industries by giving a panoply of incentives, including laws and institutions that can effectively protect intellectual property rights, to the business community, both local and foreign. This paper examines the issues of intellectual property rights in Mauritius by first surveying the main economic challenges of Mauritius, particularly the need for increased foreign investment to maintain growth, and then by discussing the various intellectual property laws enacted since the adhesion of Mauritius to the World Trade Organisation (WTO). It examines the harsh response of the law enforcement institutions and the heavy price that weaker and more vulnerable people have had to pay and queries whether Mauritius implemented the Trade Related Aspects of Intellectual Property Rights agreement mainly in order to benefit from the African Growth and Opportunity Act. The paper argues that, while the enforcement of intellectual property rights may send a positive signal to potential investors, it may also make it harder for weaker segments of the population to sustain a decent livelihood. It is proposed that the law may have to be changed to allow courts to take into account the social circumstances of a person breaching the provisions of intellectual property legislation. The role of the courts should not simply be one of inflicting punishment; they should also be capable of fostering a sense of responsibility and accountability on the part of offenders.
\end{abstract}

* Kaushik Goburdhun is a legal practitioner. He is currently Assistant Chief Legal Adviser of the Independent Commission Against Corruption, Mauritius. Email: kgoburdhun@yahoo.co.uk 


\section{Résumé}

L’économie mauricienne rencontre de graves difficultés économiques. Il est fait pression sur le gouvernement afin de préserver la compétitivité de diverses industries en accordant une série d'incitations, notamment législatives et institutionnelles, pouvant effectivement protéger les droits de propriété intellectuelle des opérateurs économiques tant nationaux que non nationaux. Cette étude analyse les questions de droits de propriété intellectuelle en commençant par passer en revue les principaux défis économiques qui se posent à l’Ile Maurice, notamment la nécessité d'accroître l'investissement étranger afin de maintenir la croissance, puis en discutant les diverses législations sur la propriété intellectuelle promulguées depuis l'adhésion de l’Ile Maurice à l'Organisation mondiale du Commerce (OMC). Il y est examiné la réaction sévère des institutions répressives et le lourd prix qu’ont du payer les populations plus faibles et plus vulnérables. Il y est aussi posé la question de savoir si l'Ile Maurice a mis en œuvre les Aspects touchant au Commerce des accords relatifs aux Droits de Propriété Intellectuelle, surtout pour bénéficier de la Loi Américaine sur la Croissance et les Débouchés en Afrique. Selon cette étude, si l'application des droits de propriété intellectuelle pourrait envoyer un signal positif aux investisseurs potentiels, il pourrait ne pas en être ainsi pour les segments les plus faibles de la population qui ont du mal à gagner décemment leur vie. Il est proposé que la loi soit modifiée afin de permettre aux tribunaux de prendre en compte les circonstances sociales d'une personne ayant enfreint les dispositions de la loi sur la propriété intellectuelle. Le rôle des tribunaux ne doit pas uniquement consister à infliger des châtiments ; ils doivent aussi pouvoir susciter chez les contrevenants un sens de la responsabilité de leurs actes.

\section{Introduction}

During the 1980s and early 1990s the small island state of Mauritius grew from a mono-crop economy into a middle-income country due to a successful diversification of its economic structures, especially through its textile, tourism and financial industries. Lately the setting up of an information technology industry has been earmarked as a new and promising economic pillar for the country. The Mauritian government is constantly working to provide a better investment climate to promote economic growth and curtail growing unemployment, increasing public sector deficits and increasing domestic debt. To this end Mauritius provides a number of incentive schemes for investors. These incentives include reduction in corporate tax, exemption from custom duties from equipment and raw materials, preferential loan rates, reduced tariffs on electricity and water and exemption from tax on dividends paid to shareholders. 
To combat unemployment, the Industrial and Vocational Training Board, a pre-vocational training institution, has been assisting the unemployed to acquire skills that are sought after in the job market. Training has also been provided to those already in employment in order to upgrade their skills in light of new technology and techniques. Training programmes are given in a variety of fields such as construction, welding, printing, textiles, agriculture and driving. It is also believed that these skills will enable many people to set up their own small to medium-sized enterprises.

As of April 2002 a total of 26,826 people were registered as unemployed in Mauritius. Table 1 below shows the breakdown of this figure in relation to level of education.

Table 1: Unemployment and Level of Education

\begin{tabular}{lc}
\hline Level of education & Number unemployed \\
\hline Education Nil & 161 \\
Std I to VI (Failed ) & 7,357 \\
Std I to VI (Passed ) & 3,271 \\
Form I to V & 4,252 \\
SC/GCE (OL) Failed & 4,531 \\
SC/GCE (OL) Passed & 3,881 \\
SC/GCE (OL) 5 credits (Including & \\
English, French and Maths ) & 287 \\
HSC (F)/GCE (AL) in 1 or 2 subjects & 1,279 \\
HSC (P)/GCE (AL) in 3 or more subjects & 1,807 \\
Total & $\mathbf{2 6 , 8 2 6}$ \\
\hline
\end{tabular}

Source: Paper submitted by the Mauritius National Commission for UNESCO Training for the Unemployed - The Programme of IVTB (Mauritius).

The rise in unemployment figures has been explained partly by mismatch between the demand and supply of labour. However it seems that training the unemployed has not played a significant role in curtailing unemployment. In 2003 unemployment figures jumped to 10.2 per cent of the labour market (approximately 54,400).

Size, location and a limited workforce are inherent handicaps with which Mauritius has to live. To make matters worse the traditional economic pillars 
have been seriously shaken recently by external events. For instance, when the EU decided to review its sugar regime in light of the decision of the WTO Appellate body in December 2005 that EU export subsidies violated the WTO Agreement on Agriculture, the EU resolved that it would cut the price of the sugar it imports from the ACP countries by a staggering 39 per cent by 2009. Although the Mauritian sugar industry has entered into a process of reform by lowering the cost of sugar production and decreasing the number of sugar mills, it is feared that the EU sugar reform will cause losses of hundreds of jobs and a significant decrease in foreign revenues.

In addition, with the lifting of Multi-Fibre Agreement quotas in 2005, the local textile industry is facing fiercer competition from China. In fact China increased its clothing exports by 64 per cent from January to April 2005, thus taking over a bigger share of the world market. African clothing exports to the US market dropped by 12 per cent during the first six months of 2005. Unless Mauritius proves to be innovative enough to take full advantage of the African Growth and Opportunity Act (AGOA), it stands to lose a golden opportunity to export several types of eligible products duty free to the US (Wong 2005).

External events can affect the local tourism industry too. Travelling to a beach resort is not such an idyllic concept to tourists any more, as the images of the brute forces of a sudden tsunami on beach resorts in Asia are still alive in the minds of many. The fear of such an event may trigger a change in the minds of some tourists who may initially have contemplated visiting a beach resort in the Indian ocean but who may, out of fear, settle for other travel destinations that are believed to be safer. Such behavioural patterns can certainly hinder economic growth. Furthermore recent world events have shown that no region in the world is safe from terrorism. A terrorist attack can seriously dampen people's enthusiasm to travel to that region.

The financial services sector has also not been spared. The double-taxation agreement with India and Mauritius had enabled Mauritius to position itself as a gateway for capital investment in India, but the recent doubletaxation agreement between India and Singapore has alarmed offshore businesses activities in Mauritius, and it is now feared that Mauritius will lose business because of the agreement between Singapore and India.

In light of these economic challenges the government has no alternative but to seek foreign direct investment (FDI) in a variety of fields to promote economic growth. However, as Table 2 below shows, Mauritius is among the poorest-performing African countries in attracting FDI. 
Table 2: Africa Country Distribution of FDI Inflows by Range 2003

\begin{tabular}{ll}
\hline Range & Economy \\
\hline More than \$2 billion & Morocco \\
\$1-1.9 billion & Angola, Equatorial Guinea, Nigeria and the Sudan \\
\$0.5-0.9 billion & $\begin{array}{l}\text { Algeria, Chad, Libyan Arab Jamahiriya, South Africa } \\
\text { and Tunisia }\end{array}$ \\
\$0.1-0.4 billion & $\begin{array}{l}\text { Cameroon, Congo, Democratic Republic of Congo, } \\
\text { Cote D’Ivoire, Egypt, Ghana, Mali, Mauritania, } \\
\text { Mozambique, Uganda, United Republic of Tanzania and }\end{array}$ \\
& $\begin{array}{l}\text { Zambia } \\
\text { Benin, Botswana, Burkina Faso, Cape Verde, Central } \\
\text { African Republic, Comoros, Djibouti, Eritrea, Ethiopia, } \\
\text { Less than }\end{array}$ \\
& $\begin{array}{l}\text { Gabon, Gambia, Guinea, Guinea-Bissau, Kenya, Lesotho, } \\
\text { Liberia, Madagascar, Malawi, Mauritius, Namibia, Niger, } \\
\text { Rwanda, Sao Tome and Principe, Senegal, Seychelles, } \\
\text { Sierra Leone, Somalia, Swaziland, Togo and Zimbabwe. }\end{array}$
\end{tabular}

Source: United Nations Conference on Trade and Development, World Investment Report 2004: The Shift towards Services.

To be successful in attracting more investment, Mauritius needs to convince investors that their intangible intellectual property assets are well protected. The Mauritius Chamber of Commerce and Industry is keen to foster awareness among Mauritian business operators of the value of their intellectual property assets, and it is believed that businesses should protect their trademarks and trade-names in order to use these in branding strategies that will make their products more marketable (Pillay 2005). It has also been argued that intellectual property rights are a major component of licensing, manufacturing, purchasing and distribution agreements and that the development of intellectual property rights legislation can contribute to a significant growth in foreign direct investment (Idris 2003).

\section{Intellectual property legislation in Mauritius}

A very strong signal that Mauritius can give to the business community is that it has complied with its WTO requirements and has actually incorporated the provisions of the Trade Related Aspects of Intellectual Property Rights Agreement (TRIPS) in its legislation. A series of laws have so far been enacted to that effect. These are the Copyright Act 1997, the Patent Industrial Designs and Trademarks Act (PIDTA) 2002, the Protection against 
Unfair Practices (Industrial Property Rights) Act 2002, the Geographical Indications Act 2002 and the Layout Designs (Topographies) and Integrated Circuits Act 2002.

The Copyright Act 1997 covers artistic, literary and scientific works. Under this act such works are deemed to include maps, lectures, musical works, audio-visual works, sound recordings, computer programmes, etc. The act also created the Mauritius Society of Authors, which has among its functions the duty to represent and defend the interests of its members in Mauritius and abroad. Any person can apply to be a member if he or she is the copyright owner or licensee of a work covered by the act. The enactment of such legislation came at a time when local artists were complaining that their works were being reproduced, sold and distributed without their consent. However the reproduction of CDs of local artists has remained rife, and this has caused local artists to re-group themselves to condemn the reproduction of their works and to ask the local enforcement authorities for more robust action.

It is usually said that Mauritians have a culture of buying cheap things and that they are not interested in procuring better CD recordings at a higher cost. Such statements ignore the fact that a large component of Mauritian Society is poor and cannot afford original CDs. In a study carried out by Duncan and Valenti (2001), it was found that 9.7 per cent of the Mauritian population lived below the poverty line and that poverty was higher in rural areas and among the creole population. However the copyright legislation is not rigid; it allows limited reproduction of certain specific works in certain circumstances without the authorisation of the copyright owner or author. The act provides that economic rights relating to the work of an author shall be protected during his lifetime and for 50 years thereafter. Furthermore, a person acting in contravention of the act is liable on first conviction to a fine not exceeding MUR 300,000 and to imprisonment not exceeding 2 years. To a subsequent offence the offender is liable to a fine not exceeding MUR 500,000 and to imprisonment for a term not exceeding 8 years.

The Patent, Industrial Designs and Trademarks Act (PIDTA) 2002 provides for the establishment of the Industrial Property Office and an Industrial Property Tribunal. The Industrial Property Office is headed by a controller whose main functions are to consider applications and grant patents and register marks, industrial designs, geographical indications or layout designs. The controller has extensive investigative powers and can apply to a judge in chambers for a right to search premises. The main functions of the tribunal are to hear appeals against decisions of the controller and to give rulings on the interpretation of any provisions of industrial property 
enactments. A patent registered with the controller will generally expire 20 years after the application filing date, while the registration of an industrial design is valid for 5 years from the filing date and is renewable for a further five years. The registration of a mark is valid for 10 years and is renewable for consecutive periods of 10 years thereafter. From the time an invention, industrial design or mark is validly registered, no person is allowed to exploit the invention, industrial design or mark without prior approval of the owner.

The Protection Against Unfair Practices (Industrial Designs) Act 2002 protects against unfair practices in the context of industrial or commercial activity. Unfair practices are defined as actions that:

- cause or are likely to cause confusion with respect to another enterprise

- damage or are likely to damage the goodwill or reputation of another enterprise

- mislead or are likely to mislead the public about another enterprise or its activities

- discredit or are likely to discredit another enterprise or its activities.

A person found guilty of an unfair practice is liable to a fine of MUR 250,000 and to a term of imprisonment not exceeding 5 years.

Two further pieces of legislation have been enacted in the context of implementing the TRIPS agreement - the Geographical Indications Act 2002 and the Layout Designs (Topographies) of Integrated Circuit Act 2002 - but have not yet been proclaimed into law. The Geographical Indications Act 2002 protects against the unfair practice of misleading the public by indicating or suggesting that a product originates in a geographical area other than the true place of origin. The act provides that such a practice may give rise to a claim in damages and also provides for criminal sanctions. The Layout Designs (Topographies) of Integrated Circuits Act 2002 provides for the protection to layout designs of integrated circuits where these layout designs are original, have not been exploited or have been exploited for a period of less than 2 years. A breach of the provisions of this act is punishable by a fine of MUR 250,000 and a term of imprisonment not exceeding 5 years.

\section{Enforcement of IP legislation}

Investors will not be satisfied simply with having laws on the books but will naturally want to know whether the law enforcement authorities are actually enforcing the laws. Combating intellectual property offences is the duty of the Anti-Piracy Unit that was set up in August 2001 within the Mauritian 
police. The unit works in close collaboration with the Mauritius Society of Authors (MASA), the Ministry of Arts and Culture and the Industrial Property Office and has investigated a number of cases of breaches of copyright and trademarks. In fact seizures of counterfeited materials are commonly reported by the press, and the press therefore plays an important role in sensitising the public that counterfeit materials are illegal and in deterring businesses from selling such materials.

Table 3 shows the outcome of cases that have been reported to the police over the past several years, as well as the number of CDs, VCDs and DVDs that have been seized.

Table 3: Copyright Infringement Cases and Outcomes

\begin{tabular}{lcccc}
\hline & 2002 & 2003 & 2004 & $2005 *$ \\
\hline $\begin{array}{l}\text { No of cases reported } \\
\begin{array}{l}\text { No of cases of Breach } \\
\text { of Copyright Act 1997 }\end{array}\end{array}$ & 97 & 60 & 63 & 41 \\
$\begin{array}{l}\text { No of cases of Breach } \\
\text { of Trademarks Act }\end{array}$ & 11 & 12 & 2 & 51 \\
$\begin{array}{l}\text { No of CDs, VCDs, } \\
\text { and DVDs seized }\end{array}$ & 29903 & 8569 & 9920 & 1087 \\
No of persons arrested & 60 & 39 & 43 & 23 \\
No of convictions & 24 & 14 & 5 & Data N/A \\
\hline
\end{tabular}

Note: * January to August 2005.

Source: Anti-Piracy Unit.

The table shows that the number of cases being reported is decreasing. Should it therefore be concluded that Mauritius is eradicating intellectual property offences? Certainly the police and the customs should be given credit for combating IP offences in Mauritius, but they can only act when there is a complainant. If the copyright or mark owner is unaware that their products are being sold without their authorisation, the practice will continue until they can act and seek redress.

The Courts in Mauritius have not been soft in dealing with people breaching intellectual property laws nor have they been homogeneous in their approach to sentencing. It is reported that persons have been sentenced to pay fines ranging from MUR 10,000 to MUR 100,000.The questions that need to be asked are: who are those people that are selling counterfeit articles, and 
why are they doing so? No person visiting Mauritius should be surprised to find that "designer" items can be obtained both from roadside sellers or in shops at very competitive prices. Most people will understand that these items are counterfeit.

However, while the roadside seller is probably a mere agent of a bigger cartel that sells counterfeited materials on the local market, the shop owner can be the importer of these counterfeited goods. Should these two lawbreakers be given the same sentence? If the shop owner has actually imported these materials and therefore played an active role in placing the counterfeit materials in the local market, one would expect a harsher sentence than for the roadside seller. However the police are not required to determine the source of counterfeit products in order to secure a conviction under the Protection Against Unfair Practices (Industrial Property Rights) Act 2002 or even under the Copyright Act 1997. The seriousness of the offence (normally determined by the number of counterfeited/pirated materials that have been seized and any relevant surrounding circumstances) and the character and history of the accused play a crucial role to sentencing. It may be that both sellers will be given the same sentence.

No one can allude to Intellectual Property Rights in Mauritius without referring to the landmark cases of Polo/Laurent Co Ltd Partnership v/s Dinoo and others (2004 SCJ 44) and Polo/Laurent Co Ltd Partnership v/s Regent Ltd and two others (2004 SCJ 45). In these cases the applicant obtained an injunction against the respondents to prevent them from trading in products bearing the various "Polo" marks. The respondents argued that, as no one had registered these marks locally, they were legally entitled to use them and that, if the injunction were granted, this would result in the loss of thousands of jobs. The court had no problem ruling that the use of the "Polo" marks was in breach of the Copyright Act 1997, finding that a copyright owner is fully entitled to the exclusive use of a design or label regardless of whether they have been registered locally. As far as the jobs issue was concerned, the court ruled as follows:

If thousands of people will be affected by the stopping of an illegality in the granting of an interlocutory order protecting the rights of the copyright owner ... the fault does not lie with the copyright owner ... but with those purveyors of other people's ideas and works who have created the situation and who have been enjoying a very lucrative market. Furthermore, especially in matters relating to the infringement of copyright or trade mark, no person must be allowed to steal and reap the fruits of those who through their skill, judgment, expense and know-how had created a work .... [I]t is fraudulent to appropriate what belonged to another and its use is contrary to 
commercial morality. No person should be allowed to obtain a free ride on the goodwill associated with the products of another.

These words must have been sweet music to the ears of foreign and local investors. Out of the 108 outlets that had been trading in Polo/Ralph Laurent garments in Mauritius, seventy-five had ceased doing so by the end of July 2004 and the remainder followed suit by the end of December 2004. The value of the goods affected was estimated by the Customs and Excise Department to be around MUR 608 million. It also estimated that an average of five people were employed per outlet. There are no statistics to show precisely how many people lost their jobs as a result of the court judgment, but there do not appear to have been job losses in the thousands as was initially feared. It is true that the entrepreneurs who benefited from a loophole in the legislation were able to make millions. There is unfortunately a tendency to look only at those who became rich. The plight of the more vulnerable usually gets "back seat" treatment. Some workers who were employed by these entrepreneurs suddenly found themselves jobless, and no one seems to care whether they were able to obtain another job. Are intellectual property rights more important than the welfare of the local citizens?

\section{AGOA, TRIPS and Africa}

Mauritius has been eager to embrace the TRIPS agreement by providing for imprisonment in cases of breach of intellectual property law. This allows Mauritius to avoid the risk of being put on the watch list of the Office of the United States Trade Representative and possibly being sanctioned by the United States. Like most other developing countries Mauritius has little choice but to comply with the TRIPS agreement in order not to antagonise the United States, as our economic survival depends largely on access to the American market for our export goods. As for AGOA this is a specifically American law that gives certain countries in Africa liberal access to the US market, as well as providing enhanced access to credit and technical expertise from the United States. It is especially crucial to the textile industry, as it provides duty-free and quota-free treatment for eligible apparel articles from qualifying African countries. The eligible articles include:

- apparel made from US yarns and fabrics

- apparel made from African yarns and fabrics (subject to a cap)

- apparel made in designated lesser-developed countries from third-country yarns and fabric (subject to a cap) 
- apparel made from yarns and fabrics not produced in commercial quantities in the United States

- certain cashmere and merino wool articles

- eligible hand-loomed, handmade or "folklore" articles and "ethnic" fabrics.

However countries qualify to receive the benefits of AGOA depending on their progress in a large number of political and economic areas including:

- establishing a market-based economy

- maintaining the rule of law and political pluralism

- eliminating barriers to US trade and investment

- combating corruption,

- $\quad$ establishing policies to reduce poverty

- making health care and educational opportunities available

- protecting human rights and workers’ rights

- eliminating child labour

- enacting and enforcing intellectual property law.

The question that arises is whether AGOA was the incentive for Mauritius to adopt IP legislation? Regardless of whether this question is answered in the affirmative or not, few will dispute that eligibility for AGOA has benefited the Mauritian economy. Neverthless petty offenders against IP laws tend to suffer unfairly.

\section{Conclusion}

I am not advocating that no protection should be given to owners of intellectual property assets. However selling a counterfeit CD or shirt is certainly different from selling dangerous drugs. People that breach IP law should not be regarded as criminals if they do so for the purpose of meeting their subsistence needs or catering for the basic needs of their families.

For dealing with petty offenders, legislation should be enacted to make it mandatory for the courts to consider imposing community service orders instead of fines or imprisonment. This would not be in contravention of the TRIPS agreement, which does not exclude community service as a form of punishment. The fact of being prosecuted and being sentenced by a court of law is itself a deterrent, and adopting a softer approach to sentencing may give offenders time to reflect on their actions and build new skills and there- 
fore make them less likely re-offend. The ultimate goal of the economy is to provide for the welfare of the people. Many people in Mauritius are employed in the informal sector, which usually consists of the most vulnerable persons in society. It is essential to sensitise people in general and those forming part of more vulnerable groups that they can be part of a wealthier society. Inflicting heavy fines on these vulnerable groups and ultimately putting them behind bars are not proper steps in that direction.

Countries should not enforce legislation solely for the benefit of the rich and powerful while sidelining the needs and aspirations of the poor. Finding a balance between enforcing intellectual property rights and alleviating the plight of the poor is no easy task, but unless we find ways to do so, developing counties like Mauritius may find that their international obligations have made a large proportion of their own people into second-class citizens.

\section{Note}

1 Presented at the 11th CODESRIA General Assembly, Maputo, Mozambique, in December 2005

\section{References}

Idris, K., 2003, ‘Intellectual Property: A Power Tool for Economic Growth’, Geneva: World Intellectual Property Organisation.

Pillay, B., 2005, 'Necessity Is the Mother of Inventions', Mauritius Chamber of Commerce and Industry News, 1 February.

Wong, D., 'AGOA: Its Future', Mauritius Chamber of Commerce and Industry News, 16 September. 